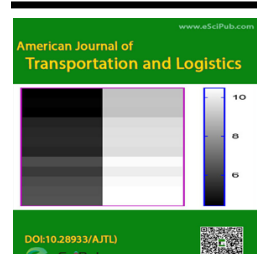

American Journal of Transportation and Logistics

(ISSN:2637-6172)

\title{
Build-Operate-Transfer Model and Its Role in Developing Railways Transport Section in Sudan
}

\section{Omar Ismail Omar Mohammad}

Sudan University of Science and Technology.

\begin{abstract}
This paper focuses on a solution to the finance restrictions that *Correspondence to Author: obstacle the development of railways section in Sudan. Sudan Omar Ismail Omar Mohammad is a big country with an area estimated at more than 1,800,000 Sudan University of Science and km2. It owns variety of natural and other resources. The Technology. transportation system in Sudan specially railways suffers a lot of restrictions that affect its contribution to the national economy. How to cite this article:

Sudan railways is one of the longest railways in Africa with about Omar Ismail Omar Mohammad. $5,000 \mathrm{~km}$. Railways were the earliest mechanical means of Build-Operate-Transfer Model and transport to be introduced in Sudan. The construction of the first Its Role in Developing Railways railway line started in the last decade of the Nineteen century. Transport Section in Sudan. AmeriRailways have been playing a significant role in transportation can Journal of Transportation and for long time. However, railways in Sudan lack passengers' trains Logistics, 2020; 3:17. recently. Moreover, the capacity of freight trains is enough to meet just $10 \%$ of needed capacity. Also, most of the rails are very old and exceeded their expire date; and as the result a lot of derailments had been occurred. Also, most of the rail on the western lines are not suited to all of the diesels. Moreover, most sleepers are creosoted wood which differ from that used

\section{eScî́Pub}

eSciPub LLC, Houston, TX USA. Website: https://escipub.com/ in the neighboring countries that use steel or concrete. And to overcome all these issues, there is a huge need of finance. However, lacking of finance is one of the main restrictions that face the development of railways section in Sudan. And, in spite of that, the Build Operate-Transport (BOT) approach could be the
\end{abstract}


best option to deal with the current situation that faces railways section in Sudan. Build-OperateTransport Approach (BOT) is a well-known method of initiating, financing and managing public capital projects by private section for specific period of time and then transfer them to the public owners. The idea of the approach is to give the private and nongovernmental section the opportunity to invest in public capital projects like infrastructure, telecommunication, and other projects which had been used to construct by the public section and classified as a part of 'Country's Sovereign' for many countries. And these projects require huge amount of finance that may not be available for a lot of countries. At the same time, achieving these projects is very vital for the development of any country. BOT system helped a lot of country to get the advanced technology and improve management skills. In addition, BOT system increased the efficiency and productivity. And support many countries to avoid the risk of getting loans in order to finance the capital projects and therefore creating economic growth. Using BOT approach to finance railways project was experienced in Turkey since 1984. And starting from 1980's until 1992, the BOT system become familiar and more than 190 billion USD projects had been financed by this approach in 47 countries. This study finds out that BOT approach could be the proper way to generate the requested finance and management to overcome the existence problems that restrict the development of railways section in Sudan.

Keywords: Build-Operate-Transfer Model; Developing Railways; Sudan

\section{INTRODUCTION}

The railway system in Sudan has been vital for many years partly because of its ability to shift the large volume of agricultural exports produced in the country, and at low cost. In addition, it is able to transport inland the increasing imports of heavy capital equipment and construction materials needed for development, such as apparatus for oil exploration and for drilling operations (leading Edge 2016). The Sudan Railways constitutes the largest rail system in Tropical Africa, with 4,756 km (almost 3,000 miles) of line (Due, 2011). Railways were the earliest mechanical means of transport to be introduced in Sudan. The construction of the first railway line started in the 1890s, and stretched from the north of the country down to Khartoum. The idea was to facilitate the advance of the Anglo-Egyptian army. Today, Sudan has an extensive rail network - almost 5,000km long — which serves mainly the northern and central parts of the country (Leading Edge, 2016). Efforts to improve the rail system in the late 1970 s and the 1980 s included laying heavier rails, repairing and purchasing new equipment, and improving training and repair facilities. Foreign governments and international organizations provided substantial assistance to fund these projects. Implementation of much of this work was hampered by political instability, debt, the dearth of hard currency, the shortage of spare parts, and import controls. By the late 1990s, the system was in poor condition and required substantial refurbishment and investment in new signalling systems, and addition of double tracks to increase both capacity and speed. The rolling stock had deteriorated as a result of poor maintenance, low investment, and age; as much as half the rolling stock was out of service. In 2006 the network carried only 1.3 milliontonnes of freight and 61,000 
passengers, a decrease from the previous year. Figures for 2010 were 1million tonnes and 47,000 passengers (Berry, 2015).

\section{CONCEPTUAL CLARIFICATION}

\section{Build-Operate-Transfer (BOT) Model}

Build-Operate-Transfer is a concept used to describe an aspect of public-private initiative in executing capital intensive projects. It is a process whereby public can partner with private sector in executing capital project and infrastructure. Also, this could be referred to as a form of project financing mechanism that helps a private entity to obtain a concession from public to finance, design, construct and manage a facility (Lekan, 2013). Build - Operate - Transfer (BOT) is a relatively new approach to infrastructure development, which enables direct private sector investment in large-scale projects such as roads, irrigation, telecommunication, bridges and power plants Lema (2002). One of the major emerging projects financing system is Build-OperateTransfer (BOT). It enables client to have access to fund for construction on event of fund insufficiency. It involves financing partnership between a private and government with parties involved receiving concession on design, planning, funding, execution and management of a project. The system provides an opportunity for a project to be managed after completions to enable the proponents recover the sum invested in the project. The need to execute project effectively and given the high cost of execution of environmental projects necessitates government sourcing of private initiative. In the case of this type of arrangement, private undertakes the project funding before being transfer to the government (Zhang, 2005). The Build-Operate-Transfer (BOT) approach is part of a range of ways with which the private sector participates in infrastructure provision. It has been widely viewed as a pragmatic approach in infrastructure provision in countries where severe budgetary constraints limit government's capacity to provide it (Llanto, 2008). Build-Operate-Transfer is a concept used to describe an aspect of public-private initiative in executing capital intensive projects. It is a process whereby public can partner with private sector in executing capital project and infrastructure. Also, this could be referred to as a form of project financing mechanism that helps a private entity to obtain a concession from public to finance, design, construct and manage a facility. On a typical BOT project, the financier looks primarily to the project as only means of loan repayment in case loan facility is accessed in the project financing; this is usually premised on the credit worthiness assessment of the project at feasibility stage. So also, it involves security assurance, security taken on a typical BOT project which is often restricted within the project portfolio. BOT mechanism is a complex structure comprising multiple, inter-dependent agreements among various parties. Some of such parties includes: government, private company (concessionaire), lenders (banks), equity investors, contractors, suppliers, operators and financial advisers. Government grants concession to the private sector (concessionaire), through concession agreement. The concessionaire is responsible for design, finance, construction, and operation of the facility (Lekan, 2013).

\section{Significant of Build-Operate-Transfer Model}

Considering the large investments, the technical expertise, and the length of commitment that are involved, BOT projects present a unique opportunity for the transfer of technology to the developing countries (Antonio and Miroslaw, 2007). In Pakistan, development of an appropriately cost effective and robust infrastructure is a pre-requisite for economic growth of the country. Such like development at national level warrants availability of huge financial outlays involving use of 
public funds and foreign investments at the cost of other equally important social sector works. The government often in meeting development targets has drained its meagre financial resources. It is therefore necessary adoption of an indirect approach i.e. BOT. In the last decade, the Government of Pakistan (GOP) has been facing financial limitations, liabilities and constraints in the development of various infrastructure projects. So, the GOP has tried to coup up with the situation by introducing the BOT. In order to protect its own financial liabilities and to inject the finance from private sector and foreign countries in the infrastructure development, the GOP launched various BOT projects in Pakistan (Khan, 2008). It is believed that by creating a more competitive environment, well-coordinated privatisation program through BOT model in developing countries will increase utilization of external sources of new advanced technology, improve management skills, and maximize overall effificiency and productivity (Cabrera 2015). The build operates and transfer (BOT) approach to develop infrastructure projects and facilities of public interest such as bridges, airports, power plants, detention facilities, parking facilities etc is an alternative for a country that lacks the appropriate funds to undertake on its own projects of this scale (Yiannis and Demos, 2005). Globally research and implementation on BOT project delivery system has directed various effective routes to utilize private sector funds, technology innovation, management skills and operational efficiencies for the development of public infrastructure (Khan, 2008). The main reason for privatisation of state-owned enterprises in Turkmenistan is to improve overall performance and achieve sustainable economic growth. As an instrument for this purpose, the nature of the BOT model is to allow private sector participation in owning and managing infrastructure enterprises
(Erdogan, 2010). Privatisation can provide an alternative fifinancing approach and BOT can provide a vehicle to achieve ambitious infrastructure development within the public regime (Hensley and White, 1993).

\section{Build-Operate-Transfer Model Experience}

The first official private facility development under the name "Build-OperateTransfer" was used in Turkey in 1984 to develop infrastructure. Private financing was used to develop railways and roads in the western world in the second half of the nineteenth century (Menheere and Pollalis, 1996). Although the term Build - Operate - Transfer is relatively new, the practice of permitting private concerns to develop and operate infrastructure projects has been around for several years. By October 1992, there had been over 70 projects valued at USD 30 Billion in 14 countries that had been financed since mid-1980's. At least another 100 projects in 33 countries (mostly in Europe) worth USD 160 Billion were identified as being in some stage of planning or development. In Europe, such projects were called "Concessions". The government, in such projects would establish the major objective of a particular project and assume the role of defender of the public interest, but would allow a private company or consortium to design, finance, construct and operate the particular project for a certain concession period (Levy, 1996). The Philippines was reported as the first country in Southeast Asia to enact a BOT law and the Ramos administration successfully used it to solve the critical power problem of the nineties (Llanto, 2008). Build-Operate-Transfer method has been successfully deployed in the execution of capital projects in countries like United States of America, Japan, Indonesia, Malaysia, Singapore, India, Canada, and United Kingdom among others, and most recent in Nigeria in Power, Energy, Telecommunication and Transportation projects (Lekan, 2013). 
The BOT concept is working well in Hong Kong, with particular reference to the five tunnels on which it has been applied (Zhang and Kumaraswamy, 2001).

\section{RAILWAYS IN SUDAN}

\section{Historical Background}

Sudan railways is one of the longest railways in Africa. It operates a $4578 \mathrm{~km}$ (SRC, 2007). The railway system, with 4,756 kilometres of line (2,956 miles) is currently the largest single system in all tropical Africa, second to East African Railways when that system functions as a unit. Furthermore, the Sudan remained almost entirely dependent on rail transport longer than virtually any other country in the world; only since the early 1970s has road transport come to play any significant role in transport, although it is now expanding rapidly. (Due,2011). Railways were the earliest mechanical means of transport to be introduced in Sudan. The construction of the first railway line started in the 1890s, and stretched from the north of the country down to Khartoum. The idea was to facilitate the advance of the Anglo-Egyptian army. Today, Sudan has an extensive rail network - almost $5,000 \mathrm{~km}$ long - which serves mainly the northern and central parts of the country (leading Edge, 2016). The first line, built south from Wadi Halfa along the Nile as a part of the military expedition to rescue General Gordon, was ultimately abandoned in 1905. The new direct line reached Khartoum in 1899. The final line, to Wau, was completed only in 1961. The system, unlike the others in the study, is isolated from those of other countries and thus there is no rail transit traffic or exchange of cars. Only a short gap once separated the Sudan and the Eritrean systems, but the latter is not now functioning. The gauge, $1.067 \mathrm{~m}$., is the same as that of southern Africa but not of Kenya and Uganda. The railway is a statutory corporation, wholly owned by the government
(Due, 2011). The first segment of present-day Sudan Railways, from Wadi Halfa to Abu Hamad, was built by the British for use in General Herbert Kitchener's drive against the Mahdiyyah in the late 1890s. The line reached Atbarah during the campaign and, after the defeat of the Mahdiyyah in 1898, extended to Khartoum. The line was built to 1.07 meter gauge track, the result apparently of Kitchener's pragmatic use of the rolling stock and rails of that gauge from an older line. This gauge was used in all later Sudanese mainline construction. In 1904 construction began on a new line from Atbarah to the Red Sea. In 1906 the new line reached recently built Port Sudan to provide a direct connection between Khartoum and ocean-going transport. During the same decade, a new line connected Khartoum southward to Sinnar, the heart of the cotton-growing region. A westward continuation reached $\mathrm{Al}$ Obeid in 1911, when it was the second largest city and center of gum arabic production. In the north, a branch line that tied the navigable stretch of the Nile between the fourth and third cataracts into the transport system was built from near Abu Hamad to Kuraymah. In the mid- and late 1920s, a spur of the railroad linked Taqatu Hayya, a point on the main line 200 kilometres southwest of Port Sudan, southward to the cotton-producing area near Kassala, then on to the grain region of Al-Gedaref, and finally to a junction with the main line at Sinnar. An extensionconnected Sinnar to Al-Damazin on the Blue Nile. Additional construction in the 1950s included an extension of the western line to Nyala in 1959 in Darfur and a south-westerly branch to Wau in1961 (Berry, 2015).

\section{Railway Problems and Restrictions}

"The entire railway network is broken down," head of the railway Mr Mckawi Awad Mckawi told Reuters. "We have no more passenger trains while the capacity of freight trains is only enough 
to meet $10 \%$ of the transportation needs of Sudan." (Smith, 2013). The main line from Port Sudan via Atbara to Khartoum has $90 \mathrm{lb}$. rail, which is being extended to Sinnar. This is an adequate weight. The secondary main lines Khartoum to El Obeid, Halfa to Sinnar, and Atbara to \#10 Junction have $75 \mathrm{lb}$. rail; the remainder, 50 . Most of the rail on the western lines is $50 \mathrm{lb}$. relay rail taken from the main line as it was upgraded. Much of the light rail dates back to 1910 and some to the turn of the century. Some of the rail is worn, but it is not on the whole in bad shape, though the $50 \mathrm{lb}$. rail is too light for many of the diesels. Most sleepers are creosoted wood, unlike the countries to the south that use steel or concrete. Some sleepers are produced in the country, but many are imported, especially from Malaysia; all must go to Atbara for creosoting. The life is estimated from 15 to 25 years. Many of the existing sleepers are termite eaten, and the telephone poles are particularly vulnerable to termites. No serious consideration has been given to other than wood sleepers. The ballast is poor; some is rock, but a substantial amount is dirt. The ballast has been neglected over recent years, and the poor condition results in slow orders, derailments, and rail wear. A five-mile segment on the Halfa Port Sudan main line has been a particular source of derailment. For another example, in the last year in the west, the number of derailments per month between Elrahad and Babanousa was 9, Babanousa-Wau, 2, Babanousa-Nyala, 2 (Due, 2011). Considerable investments are wanting for the rehabilitation of the existing railway infrastructure in Sudan, and in particular for carrying out the proposal to move from narrow gauge track to wide gauge (Leading Edge, 2016).

The freight train rumbles over the Blue Nile bridge and snakes through the capital. It could take weeks to reach its destination, in Darfur, for despite the potential to link up a divided nation, Sudan's railways are derelict, after years of sanctions and neglect. "There are passenger trains still running. But they are very rare," admitted Mohammed Ahmed Makkawi, the general manager of Sudan Railways Corporation.Sudan's railways prospered in the 1960s and 1970s, driven by a thriving agricultural sector and foreign investment, and their decline mirrors the wider stagnation of the Sudanese economy. Like other officials in the sector, Makkawi blames the poor state of Sudan's narrow-gauge train system on US economic sanctions, first imposed in 1997 and renewed as recently as November. "Most of our locomotives are from America, but most of them are out of service because of sanctions. We can't get spare parts," he said. "We are trying to get financing for another track, to make it a standard gauge, so that it can carry a lot of equipment and goods and passengers, and be much more reliable," he added. Khartoum has managed to buy new locomotives from China in recent years. But plans to build a new line from Port Sudan to Khartoum, the busiest route, would cost an estimated $\$ 1$ billion (or 705 billion euros), money that the destitute Sudanese government simply does not have. "The existing tracks are very old," Makkawi said. Most of the tracks are indeed ancient -- a staggering 73 percent of the railway lines were constructed before 1930 -- with the 50-kilometre branch line connecting Muglad to the Abu Jabra oil field being one of just a few to be built in the last half century (MEO, 2011). The Sudan Railways Corporation (SRC)has embarked on the rehabilitation and upgrading of the rail line from Babanousa, through El Daein to Nyala $(375 \mathrm{~km})$ in order to increase speed and load efficiency along the sections. Rehabilitation or reconstruction of approximately $113 \mathrm{~km}$ of the first phase form Babanousa to Abu Jabra has been completed using 
new rails and semi-ballast track. The second phase from Abu Jabra to Nyala requires US $\$ 200$ million, which is not yet available. It is expected that trainload capacity and speed will increase, resulting in higher performance of the lines after completion of the upgrades (AFDB, 2016).

\section{Railway Prospective Projects in Sudan}

In its Railway Strategy (2013-2017), the Sudan Railway Corporation proposed to restore a number of key lines, including the Khartoum-Port Sudan line, and to link more Sudanese regions by railway lines. Considerable investments are wanting for the rehabilitation of the existing railway infrastructure, and in particular for carrying out the proposal to move from narrow gauge track to wide gauge (Leading Edge, 2016). SUDANESE Railway Corporation (SRC) is reportedly in negotiations with Ukraine, Korea, and China as it prepares to issue a tender in the next few months for 10 locomotives as well as track materials to rehabilitate about $1000 \mathrm{~km}$ of railway. The project could be worth up to \$US $500 \mathrm{~m}$ in its initial stages. The Sudanese government is keen to boost export of livestock as well as cotton and gum arabic - an edible gum material used in soft drinks and drugs - to aid the country's ailing economy which is suffering from the loss of much of its oil revenues since the split with South Sudan. It considers rebuilding the railway as the most effective way of doing this and is actively working with the Chinese, the country's biggest aid donor, as well as Korea. "We need the railway," says transport minister Ahmed Babiker Nahar. "Road traffic is expensive. The railway is cheaper, faster, safer and has a bigger capacity. Livestock arrives in better condition by rail." SRC aims to renew $1000-2000 \mathrm{~km}$ of track in the next two years, and has already reintroduced a daily freight train from Khartoum to Atbara, which is $300 \mathrm{~km}$ north of the capital, and from the line to Port Sudan is now being rebuilt. There are also plans to restart services on the line from Khartoum to Nyala in Darfur via North Kordofan state, the main gum Arabic production site, and to extend the line from Nyala into Chad. The rehabilitated railway could also be used to transport oil from South Sudan if the country can reach an agreement (Smith, 2013).

\section{CONCLUSION AND RECOMMENDATIONS}

Sudan is a big country and railways had been one of the most important means of transportation in Sudan. This section is facing a progressing decline in the last decades and the railways infrastructures are almost destroyed. Therefore, we can conclude this paper with the following: 1Build-Operate-Transfer (BOT) model is an important financing mechanism that helps public sector and governments to obtain a finance to design, construct and manage public projects that help the development of the country and/or state and maintain economy's growth. 2- (BOT) helps countries avoid the risk of getting capital loans to finance infrastructure and other public projects; and, therefore, guarantees no more liabilities that negatively affect the growth of economy. 3-Adapting BOT model in developing countries is very important to increase utilization of external sources of new advanced technology, improve management skills, and maximize overall effificiency and productivity. 4- Sudan has one of the longest railways in Africa and it had been very vital to economic growth for long time since it was the earliest mechanical means of transport to be introduced in Sudan. 5- Railways in Sudan is facing many issues now such as lacking passengers' and freight trains. Also, most of the rails are very old and exceeded their expire date. 6The public section has no enough finance to be invested in the railways section and the opportunity to get enough loans and finance from regional international organizations is not available due to economic and political restrictions face 
Sudanese government. Therefore, we recommend the following: 1- The Sudanese government should start initiating the (BOT) model in order to execute public infrastructure projects. 2As the operating of projects takes long time before been transferred to the public ownership which may affect the quality of the final projects' outputs, the governmental agencies and parliament should enact appropriate legislations that help maintain the quality of project outputs by stressing the necessity and obligatory to provide continuous maintenance for projects. 3- Railways corporation in Sudan should bid private sector locally and internationally to invest in building and operating some railways lines insisting the importance of having clear, fair, and appropriate agreements that satisfy all stakeholders. 4- The Central Bank of Sudan should legislate and motivate banking section to provide required facilities to the local private companies and investors to start investing in local public railways projects as well as other local public infrastructure projects.

\section{References}

[1] AFDB (2016). SUDAN: DARFURINFRASTRUCTUREDEVELOPMENT REPORT. Retrieved from

https://www.afdb.org/fileadmin/upl oads/afdb/Do cuments/Knowledge/

Sudant-Darfur_Infrastructure_Development_Report_-_06_Feb_2017.pdf

[2] Antonio, L., and Miroslaw, J.S. (2007). "Technology transfer in BOT projects". Proceedings of ASCE Construction Research Congress: The Global Construction Community, May 6-8, 2007, Grand Bahama Island.

[3] Berry (2015). Sudan: a country Study. Library of Congress. Federal Research Division.

[4] Due (2013). Trends in Rail Transport in Four African Countries Zimbabwe, Zambia, Tanzania, Sudan. Retrieved from http://www.archive.org/details/trendsinrailtran937duej

[5] Due (2011). RAIL AND ROAD TRANSPORT IN THE SUDAN. Retrieved from

http://www.archive.org/details/railroadtranspor423duej

[6] Cabrera, M., Suarez-Aleman, A., Trujillo, L., (2015). Public-private partnerships in Spanish ports: current status and future prospects. Util. Policy 32 (2015), 1e11.

[7] Erdogan, H., (2010). Build-operate-transfer as an alternative for fifinancing municipal investments: the case of Antalya Sarisu Picnic Area, Suleyman Demirel University. J. Fac. Econ. Adm. Sci. 15 (3), 471e486.

[8] Hensley and White (1993). The Privatization Experience in Malaysia: Integrating Build-OperateOwn and Build-Operate-Transfer techniques 16 within the national privatization strategy. The Columbia Journal of World Business.

[9] Khan (2008). The Trend of Build Operate and Transfer (BOT) Projects in Pakistan. Retrieved from

https://www.researchgate.net/publication/335977256_The_Trend_of_Build_Operate_and_Transfer_BOT_Projects_in_Pakistan

[10] Leading Edge (2016). Sudan's transport system a key cog in economic development. Retrieved from

https://www.leadingedgeguides.com/guide-sudan-2016-transporteconomic-development/

[11] Lekan (2013). Performance of Build-OperateTransfer Projects: Risks' Cost Implications from Professionals and Concessionaires Perspective. Retrieved from https://www.researchgate.net/publication/282133476_PERFORMANCE_OF_BUILDOPERATETRANSFER_PROJECTS_RISKS'_COST_IMPLICATIONS_FROM_PROFESSIOALS_AND_CONCESSIONAIRES_PERSPECTIVE 
[12] Lema (2002). An Assessment of the Build-Operate-Transfer (BOT) Model for Infrastructure Project Financing in Tanzania. Retrieved from https://www.semanticscholar.org/paper/An-Assessment-of-the-Build-OperateTransfer(BOT-)Lema/3daefbe8c37e56d86f1cced58a0be a176b5cd43c

[13] Levy S M (1996) Build - Operate - Transfer, paving the way for tomorrows' infrastructure, John Wiley \& Sons, New York, pp. 1-25.

[14] Llanto, G. (2008). Build-Operate-Transfer for Infrastructure Development: Lessons from the Philippine Experience, in Kumar, N. (ed.), International Infrastructure Development in East Asia - Towards Balanced Regional Development and Integration, ERIA Research Project Report 20072, Chiba: IDE-JETRO, pp.319-359.17

[15] Menheere Sebastian and Spiro Pollalis (1996). Case Studies on Build-Operate-Transfer. Netherlands: Delft University of Technology.

[16] MEO (2011). Sudan's railways ran out of steam. Retrieved From:

https://middle-east-online.com/en/sudan\%E2\%80\%99s-railways-ranout-steam
[17] Smith (2013). Sudan looks to rebuild war-ravaged railway. Retrieved from https://www.railjournal.com/africa/sudan-lookstorebuild-war-ravaged-railway/

[18] SRC (2007). Facts \& Figures Year 2007. Retrieved from https://web.archive.org/web/20160820112824/http://sudanrailways.gov.sd/wpcontent/uploads/2014/05/facts_2007_en.pdf

[19] Yiannis and Demos (2005). "The financial risks in build operate and transfer projects". Journal of Construction Management and Economics, Volume 23, pp 431-441, Taylor \& Francis Group Limited.

[20] Zhang, X. (2005) Criteria for Selecting the Private Sector Partner in Public-Private Partnership. Journal of Construction Engineering and Management 13, (6) 631-44

[21] 21- Zhang, X.Q., and Kumaraswamy, M.M. (2001). "Hong Kong experience in managing BOT projects". Journal of Construction Engineering and Management, pp 154-162, ASCE.

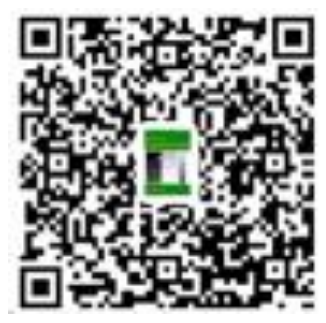

